\title{
AGROECOLOGICAL INFLUENCE OF MICRONUTRIENT FETILIZERS AND SEED INOCULATION ON A SOYBEAN CROP
}

\author{
Inna Fedoruk ${ }^{1}$ \\ fedoryk_i15@ukr.net \\ Oleg Bakhmat \\ Department of Ecology, Quarantine and Plant Protection ${ }^{2}$ \\ gerbah@ukr.net \\ Yuri Khmelianchyshyn ${ }^{1}$ \\ hmelya75@ukr.net \\ Olesia Gorodyska \\ Department of Agrochemistry, Chemical and General Biological Disciplines ${ }^{2}$ \\ olesya_pv@ukr.net \\ ${ }^{1}$ Department of Crop Production and Forage Production ${ }^{2}$ \\ ${ }^{2}$ State Agrarian and Engineering University in Podilia \\ 13 Shevchenka str., Kamianets-Podilskyi, Ukraine, 32316
}

\begin{abstract}
The practical experience substantiates the need to treat soybean seeds with high-quality inoculants and VuksalKoMo 15 with the trace elements content of cobalt and molybdenum. The processes of inoculation of seeds in the form of rhizobial bacteria significantly improve the soy plants ability to fix atmospheric nitrogen in the early stages of development. We begin to observe the rhizobial formation on the corinium soybean system already at the stage of BBCH 12-13. This in turn will affect the yield and productivity of Rosin soybeans.

One of the important aspects of soybean cultivation is providing not only macroelements, NPK, Ca, S, but also microelements.

Carrying out experiments on the effect of seed inoculation on soybean yield, we combined an inoculant, VuksalKoMo preparation and Sdandak Top insecticidal fungicide preparation with a sowing period of up to 5-7 days in a tank mixture. One of the main requirements is the use of high-quality inoculants with a high content of viable nitrogen-fixing bacteria for processing soybean seeds. This, in turn, will ensure high yields of soybeans with optimal costs and the fastest return on investment, especially in today's conditions.

The research results are aimed at solving urgent problems in the technology of growing leguminous crops, namely: developing a version of the technology for growing soybeans for the selection of varieties, adapted to a given climatic zone, the use of inoculants and micronutrients in the conditions of climate change.

Keywords: variety, inoculation; trace elements; symbiotic nitrogen fixation; biological cultivation; grain yield.

\section{Introduction}

Among crops, that recently occupy a leading place in the agricultural industry of Ukraine, a significant role belongs to soy. Wide possibilities of use, a consistently high demand in the market, including export, soil enrichment with nitrogen and, as a result, a favorable effect on crop rotation, as well as adaptability of cultivation stimulate the growth of crop areas to almost 2 million hectares.

Soybean is one of the most valuable oilseeds. The completeness of food products is determined by the protein content and its quality. A lack of protein leads to disorders in the physiological and functional functioning of the body. According to the FAO (Food and Agriculture Organization), the protein intake should be $12 \%$ of the total calorie intake of a person's daily diet or $90-100$ g, including $60-70 \%$ of animal protein. In animals, the body cannot synthesize protein from inorganic substances, but creates it from plant protein.
\end{abstract}

DOI: 10.21303/2504-5695.2021.001747 
The vegetable protein problem can be solved by growing legumes. Legumes in the farming system play an important role, which is associated with their ability to fix atmospheric nitrogen of the air with the help of nodule bacteria and enrich the soil with it.

The chemical composition of a soybean plant can vary significantly depending on the fertility of the soil and the balance of nutrients in it. Under optimal conditions, plants show the same composition regardless of the growing zone. Accordingly, $90 \%$ of the dry matter of plants is carbon dioxide, hydrogen and oxygen from the air. However, they are not fully assimilated if the soil has an insufficient amount of other macro- and microelements.

The lack of trace elements reduces productivity, causes disease damage, affects the grain quality. Microelements are extremely important for the soybeans growth and development, since their presence in sufficient quantities is a prerequisite for intensive assimilation of nitrogen from the air [1].

Soya plays a significant role in biological farming. It fixes nitrogen from the air, providing them with $60-70 \%$ of its needs and leaves it in the soil along with plant residues after harvest. The introduction of scientifically based technology for soybean cultivation allows to obtain 2.5-3.0 t/ha of seeds $[2,3]$.

However, a weighty argument, one of the main issues in technology, is the processing of high-inoculum seed inoculant.

Inoculation of the seeds of legumes with bacterial preparations (inoculant) has a significant biological potential of soils, in particular, due to legumes that form symbiotic bonds with microorganisms, it is in the soil. Bacteria (rhizobia) sprout in the form of thin hairs and become inflated. In the miscellaneous bacteria on the plant, males are assimilated by a bulbul, and in some cases bacteria are also multiplied. Cybacteria fix nitrogen from the diet, which converts to a gaseous one by assimilating the form of $\mathrm{NH}_{4}^{+}$ion ammonia for plants. Regardless of the bean inoculation, it is not necessary to remove nitrogen from the crop, but also to accumulate the nitrogen in the roots and early gratings, which will provide the successor plants with nitrogen, as well as the soil with organic nitrogen.

New environmental challenges, posed by nature to humanity, caused the need for a transition to steel-living and strong gratitude. The technology for growing soybeans with the strobing of a highly productive seed inoculum is a successful combination of the use of biological preparations and synthetic pesticides to increase economic efficiency and minimize negative environmental impacts.

First of all, soybean productivity depends on growing technology. But a weighty argument, one of the main issues in technology, is the processing of high-inoculum seed inoculant.

It is known, that rhizobia can enter the soil as part of commercial inoculants, spread by air, from seeds or cultivated as symbionts of local leguminous plants. When presowing inoculation of leguminous plants, the number of nodule bacteria entering the soil depends on the size of the seeds, the crop density, the ripeness group and the inoculation method. High-quality inoculants ensure the entry of at least $2 \times 10^{3}$ bacterial cells per seed, or at least 100 thousand bacteria per seed. With increasing frequency and soybean development, the number of rhizobia in the soil is growing rapidly due to their release from the vesicles, which die after the end of the growing season of legumes. In many cases, this ensures the dominance of inoculant strains within 5-15 years after the first, initial inoculation. Rhizobia make up a relatively small part of the soil microbiota - from 0.1 to $0.8 \%$ of its total number.

Thus, inoculation is an important element in the technology of soybean cultivation along with the use of micronutrient fertilizers [4-8].

Trace elements are absorbed by soy in a smaller amount compared to nitrogen, phosphorus, potassium, and sometimes calcium, magnesium and sulfur. Despite this, their role is no less important, and the trace elements lack leads to a significant slowdown in growth rates and lower yields.

Zinc activates a number of enzymes, participates in nitrogen metabolism in the plant and the protein formation, and also plays a major role in the formation of vesicles in the production of tryptophan amino acids. Iron is a necessary component of chlorophyll and is necessary for respira- 
tion and photosynthesis processes, the creation of light hemoglobin. Manganese plays an important role in metabolic processes, such as enzyme activation, chlorophyll synthesis, photosynthesis, and nitrate reduction. Copper plays an important role in the functioning of mitochondria and the photosynthesis improvement. Its deficiency can reduce the growth and yield of soybean plants by reducing the intensity of photosynthesis. Molybdenum is necessary for the activity of two important enzymes - nitroreductases and nitrogenases, which are necessary for the reduction of nitrates and atmospheric fixation of nitrogen, relieving the herbicidal load on the culture. Boron is necessary for the activity of the meristem and, consequently, for the growth of shoots, roots, flower organs. Cobalt plays an important role in the effective fixation of nitrogen, has a positive effect on the number and weight of nodule bacteria and the nitrogen content in the plant, which comes from the main application, as well as foliar nutrition [9-12].

The seed treatment with VuksalCoMo 15 positively affects the production of more friendly seedlings, promotes the growth and root system development. It is known the tuberculic load on the culture that activates the nitroreductase enzyme, which contributes to the biological fixation of atmospheric nitrogen.

An equally important element in soybean cultivation technology is its non-cinnamon micronutrient supplementation. Micronutrient deficiency leads to lower yields, increases the risk of disease damage, leads to a loss in seed quality. The key to effective nitrogen fixation is the balanced nutrition of roslins and their provision with micro elements boron, molybdenum, cobalt, sulfur, manganese - their balanced and plentiful selection outside cinnamon is a good harvest guarantee.

An analysis of studies and publications, in which the solution to the problem was started, shows us that micronutrients play a special role in improving the efficiency of the mineral nutrition of plants.

As noted [13], first of all, it is such microelements as: boron, molybdenum, copper, zinc, iron, manganese, cobalt, magnesium. In their absence, no plant can develop normally, since they are part of the most important enzymes, vitamins, hormones, and other physiologically active substances. Trace elements are involved in the synthesis of proteins, carbohydrates, fats, vitamins. Under their influence, the content of chlorophyll in the leaves increases, the assimilation activity of the plant increases, and the efficiency of the photosynthesis process increases.

At the initial stages of the development of the soidoid phase of budding and flowering, it consumes a small amount of NPK, but already from the flowering phase to the massive filling of beans, the time of maximum absorption of the main fertilizer elements begins. As you know, the best way to provide crops with micronutrients is foliar top dressing by spraying during the growing season in critical phases of crop development, namely: phases of 3-5 trigeminal leaves, budding and filling of the lower beans. It is in this way that we can ensure the need for crops in microelements at $100 \%[14,15]$.

The current state of the agricultural sector forms new approaches to the technology of growing crops. Growing technologies are becoming relevant, in which individual approaches to growing and providing the plant with the necessary elements during the growing season are formed in detail.

The purpose of the article: to reveal the growing technology for the formation of varietal productivity of soybeans depending on the inoculation of seeds and the micronutrient fertilizers introduction to obtain increased yield and seed quality. The basis of soybean cultivation technology using inoculants and micronutrient fertilizers is the southwestern part of the Forest-Steppe of Ukraine.

\section{Research methods}

The studies were carried out by the intensive planting technology for the western Forest-Steppe.

Agrotechnics is conventional for this zone. A precursor is winter wheat. For comprehensive evaluation of the obtained experimental results, the following observations, analyses and attendant studies were conducted according to conventional methods:

Phenological observations of main development and growth phases coming, plants density in the phase of sprouts and before harvesting, the analysis of structure elements of the harvest were conducted by testing sheaves, selected before harvesting in two non-adjacent iterations by 
the "Method of state sort testing of agricultural crops" (2000); the leaf surface area in correspondent growth phases was determined by the method of "cuttings", photosynthetic potential (PP) and photosynthesis pure productivity (PPP) of soya plants were determined by the method of A. A. Nechiporovych; the use of PAR by plants was determined by the method of K. G. Tooming, B. I. Gulyaev; the number and mass of gray bubbles were determined by the method of G. S. Posipanov.

The biological grain yield was determined by the «test sheaves» method in the phase of crop full ripeness. When evaluating the quality of seeds, the following was determined: the grain nature, the "crude" protein content in the grain of soybeans and the «crude» fat content.

The yield structure was investigated in sheaf samples, which were taken at full ripeness, on plots of $0.25 \mathrm{~m}^{2}$, in four repetitions. The sheaf mass, the number of plants, branches, beans on the main and lateral branches, seeds in a pod, the number and weight of seeds per plant, and the weight of 1000 seeds were determined. Counting of the yield was carried out from the entire accounting area of each plot. The grain harvest was brought to $100 \%$ purity and $14 \%$ moisture.

Mathematical and statistical studies of experimental data were carried out using the Microsoft Excel software package: yield data (by the analysis method of variance of multivariate complexes; correlation and regression analysis), quantitative characteristics of plants (by the method of variational series, difference, correlation, regression, etc.)

The field experiment scheme is based on the action and interaction study of three factors: $A$ - varieties (depending on the ripeness group); $B$ - micronutrient fertilizers; $C$ - inoculation.

\section{Results}

The studies were carried out at «Garant» LLC (Orynyn village, Kamianets-Podilskyi district, Khmelnytskyi region) in the field crop rotation during 2015-2018. The territorially experimental field is located in the southwestern forest-steppe part of the Khmelnytskyi region; according to the heat and humidification conditions, it belongs to the southern wet agroclimatic part of the region. The total area of the experimental plot was $198 \mathrm{~m}^{2}$, accounting area $-150 \mathrm{~m}^{2}$. Repeatability is fourfold. The way to place options in the repetition - by the method of a randomized Latin rectangle.

Having carried out studies on various ripeness groups of such soybean varieties: Maxus, Cordoba, Saska, positive results were obtained from micronutrient fertilizers. As well as from seed treatment with Standak Top 1 1/t and soybean seed treatment with inoculant and trace element with VuxalCoMo 15.

Advantages of treatment with Standak Top - extremely reliable protection against ground pests, as well as sprout flies. The use of this drug prevents the diseases development, such as fusarium, anthracnose, and moldy seeds. It promotes rooting of plants in the soil due to the accelerated development of the root system. An increase in the assimilation of the leaf apparatus surface promotes the nitroreductase activation, which, in turn, activates the photosynthesis processes work, manifests itself in the so-called AgCelence effect, plants have an intensely saturated dark green color, determines the elements of the structure of the grain yield from each experiment, plants are selected for the analysis. The main elements of the structure of the crop of soybean plants are presented in Table 1.

According to Table 1, the yield indicators of 2015 are quite high, a particularly high indicator in the experiment with seed treatment with inoculant HaiKot for varietal Saska (3.06 t/ha), and also in the experiment with seed treatment with inoculant Chi Stoke+Let Kot+Vuksal Boron in Cordoba varieties (3.14t/ha), Saska (3.20 t/ha). High yields are shown by the experiment with seed treatment with the inoculant Let Kot+VuksalBoron+Bospholiarna varietal Cordoba (2.94 t/ha), Saska (3.28 t/ha), as well as the experience with seed treatment with the inoculant Chi Stoke+Let Kot+VuksalBoron+Bospholiarna varietal Cordoba (3.20 t/ha), Saska (33.5 t/ha).

When using inoculants in the conditions of the 2016 season, we observe a different effect on yield, depending on the ripeness group of varieties. Variety Maxus to the control gave an increase of $0.12 \mathrm{t} /$ gado $0.72 \mathrm{t} / \mathrm{ha}$, while Cordoba from $0.26 \mathrm{t} /$ ha to $0.71 \mathrm{t} / \mathrm{ha}$ and the late-ripening Saska variety in conditions of moisture lack failed to fully form a potential crop and yield growth ranged from $0.06 \mathrm{t} /$ ha to $0.34 \mathrm{t} /$ ha. 
Table 1

Grain yield of soybean varieties in the experiment, c/ha

\begin{tabular}{|c|c|c|c|c|}
\hline \multirow[t]{2}{*}{ Research option codes } & \multicolumn{4}{|c|}{$\begin{array}{c}\text { Soybean yield by } \\
\text { years, } t / h a\end{array}$} \\
\hline & 2015 & 2016 & 2017 & 2018 \\
\hline \multicolumn{5}{|l|}{ Sort Maksus } \\
\hline 1 & 2 & 3 & 4 & 5 \\
\hline Control (without treatments) & 1.50 & 1.32 & 1.75 & 3.78 \\
\hline Without inoculants+VuksalBoron & 1.65 & 1.35 & 1.97 & 4.03 \\
\hline Without inoculants+VuksalBoron+Bosfoliar & 1.87 & 1.36 & 2.18 & 4.31 \\
\hline Treatment with inoculant HiStick & 2.07 & 1.44 & 2.27 & 4.08 \\
\hline Inoculant treatment HiKot Super+HighKot Super Extender & 2.23 & 1.68 & 2.30 & 4.22 \\
\hline Inoculant treatment HiStick+HaiKot Super+HaiKot Super Extender & 2.12 & 1.80 & 2.63 & 4.72 \\
\hline Treatment with inoculant HiStick+VuksalBoron & 2.21 & 1.48 & 2.39 & 4.59 \\
\hline Inoculant treatment HaiKot Super+HaiKot Super Extender+VuksalBoron & 2.32 & 1.79 & 2.48 & 4.69 \\
\hline Inoculant treatment HiStick+HaiKot Super+HaiKot Super Extender+VuxalBoron & 2.29 & 1.97 & 2.77 & 5.05 \\
\hline Treatment with inoculantHiStick+VuksalBoron+Bosfoliar & 2.33 & 1.55 & 2.58 & 4.41 \\
\hline Inoculant treatment HiKot Super+HighKot Super Extender+VuksalBoron+Bosfoliar & 2.42 & 1.83 & 2.67 & 4.58 \\
\hline Inoculant treatment HiStick+HaiKot Super+HaiKot Super Extender+VukxalBoron+Bosfoliar & 2.38 & 2.04 & 2.96 & 4.53 \\
\hline \multicolumn{5}{|l|}{ Sort Cordoba } \\
\hline Control (without treatments) & 1.78 & 0.96 & 2.4 & 4.14 \\
\hline Without inoculants+VuksalBoron & 1.97 & 1.01 & 2.45 & 4.33 \\
\hline Without inoculants+VuksalBoron+Bosfoliar & 2.03 & 1.03 & 2.63 & 4.52 \\
\hline Treatment with inoculant HiStick & 2.24 & 1.22 & 2.53 & 4.48 \\
\hline Inoculant treatment HiKot Super+HighKot Super Extender & 2.70 & 1.41 & 2.67 & 4.61 \\
\hline Inoculant treatment HiStick+HaiKot Super+HaiKot Super Extender & 3.03 & 1.48 & 2.91 & 4.93 \\
\hline Treatment with inoculant HiStick+VuksalBoron & 2.39 & 1.26 & 2.47 & 4.79 \\
\hline Inoculant treatment HaiKot Super+HaiKot Super Extender+VuksalBoron & 2.83 & 1.47 & 2.86 & 4.91 \\
\hline Inoculant treatment HiStick+HaiKot Super+HaiKot Super Extender+VuxalBoron & 3.14 & 1.59 & 3.15 & 5.19 \\
\hline Treatment with inoculant HiStick+VuksalBoron+Bosfoliar & 2.45 & 1.30 & 2.69 & 4.71 \\
\hline Inoculant treatment HiKot Super+HighKot Super Extender+VuksalBoron+Bosfoliar & 2.94 & 1.52 & 3.15 & 4.84 \\
\hline Inoculant treatment HiStick+HaiKot Super+HaiKot Super Extender+VukxalBoron+Bosfoliar & 3.20 & 1.67 & 3.49 & 4.96 \\
\hline \multicolumn{5}{|l|}{ Sort Saska } \\
\hline Control (without treatments) & 1.71 & 0.83 & 2.27 & 3.28 \\
\hline Without inoculants + VuksalBoron & 1.93 & 0.85 & 2.36 & 3.44 \\
\hline Without inoculants+VuksalBoron+Bosfoliar & 2.01 & 0.86 & 2.48 & 3.51 \\
\hline Treatment with inoculant HiStick & 2.25 & 0.89 & 2.59 & 3.46 \\
\hline Inoculant treatment HiKot Super+HighKot Super Extender & 3.06 & 0.93 & 2.64 & 3.59 \\
\hline Inoculant treatment HiStick + HaiKot Super+HaiKot Super Extender & 3.16 & 1.05 & 2.73 & 3.85 \\
\hline Treatment with inoculant HiStick+VuksalBoron & 2.45 & 0.93 & 2.88 & 4.25 \\
\hline Inoculant treatment HaiKot Super+HaiKot Super Extender+VuksalBoron & 3.15 & 0.98 & 2.95 & 4.13 \\
\hline Inoculant treatment HiStick+HaiKot Super+HaiKot Super Extender+VuxalBoron & 3.20 & 1.14 & 2.92 & 4.37 \\
\hline Treatment with inoculant HiStick+VuksalBoron+Bosfoliar & 2.59 & 0.94 & 2.64 & 3.62 \\
\hline Inoculant treatment HiKot Super+HighKot Super Extender+VuksalBoron+Bosfoliar & 3.28 & 1.00 & 2.39 & 3.85 \\
\hline Inoculant treatment HiStick+HaiKot Super+HaiKot Super Extender+VukxalBoron+Bosfoliar & 3.35 & 1.17 & 2.67 & 3.71 \\
\hline $\begin{array}{ll}2-20 \\
\text { A }\end{array}$ & 0.06 & 0.08 & 0.07 & 0.07 \\
\hline B & 0.06 & 0.08 & 0.07 & 0.07 \\
\hline \multirow{5}{*}{$\begin{array}{c}\text { HIP05 } \\
\text { The smallest significant difference }\end{array}$} & 0.07 & 0.10 & 0.08 & 0.09 \\
\hline & 0.10 & 0.15 & 0.12 & 0.13 \\
\hline & 0.12 & 0.17 & 0.14 & 0.15 \\
\hline & 0.12 & 0.17 & 0.14 & 0.15 \\
\hline & 0.03 & 0.05 & 0.04 & 0.04 \\
\hline
\end{tabular}


As you can see, the largest increase in varieties Maxus and Cordoba was obtained from the use of the inoculant Hai Kot and an even better result was with the use of the minoculant Hai Kot and Chi Stoke, where we see a yield increase of $2.71 \mathrm{t} / \mathrm{ha}-5.42 \%$, which is $0.63-0.65 \mathrm{t} / \mathrm{ha}$ (Fig. 1). In the late-ripening Saska cultivars, at the use of Vuksal Boron in areas, treated with the inoculant Chi Stoke yields, a yield increase is of $0.10 \mathrm{t} / \mathrm{ha}$, while in the variants using the inoculant Hai Kot/ ha $0.15 \mathrm{t} /$ ha and Hai Kot+Chi Stoke, an increase from Vuksal Boron is $0.31 \mathrm{t} / \mathrm{ha}$.

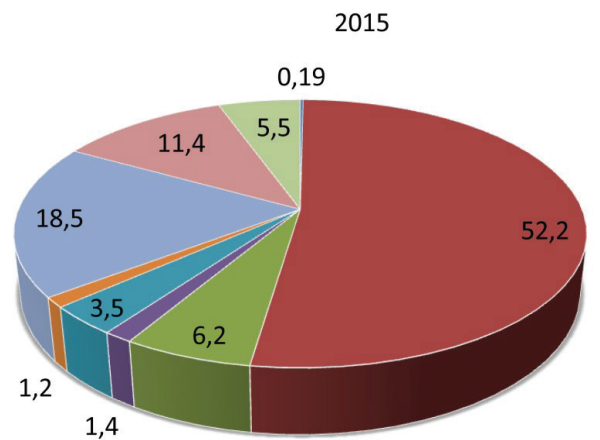

$a$

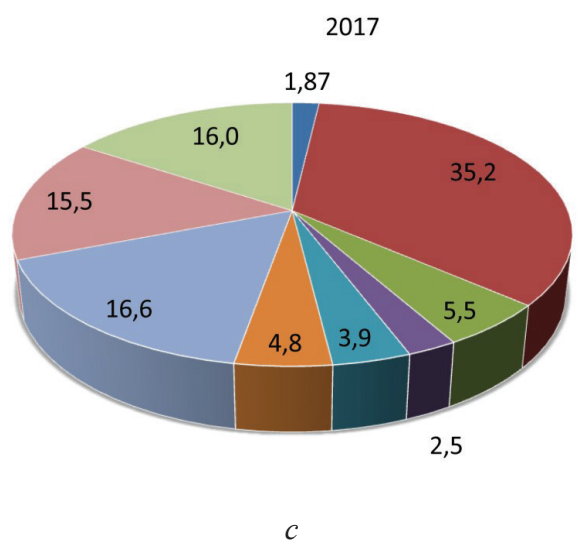

$\mathrm{cp}=$

$\mathrm{a}=$

$\square=$

$\mathrm{C}=$

$\mathrm{cab}=$

$\mathrm{cac}=$

$\mathrm{cbc}=$

cabc=

- $\mathrm{cz}=$

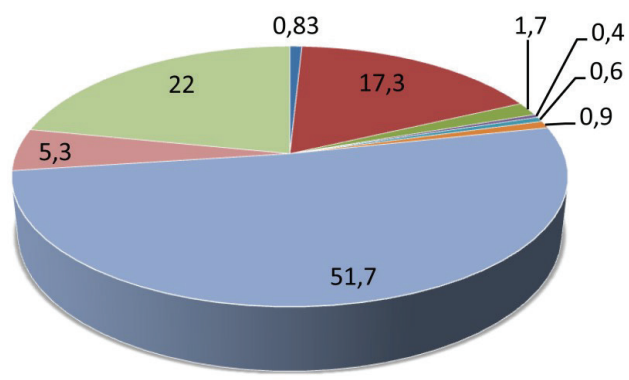

b

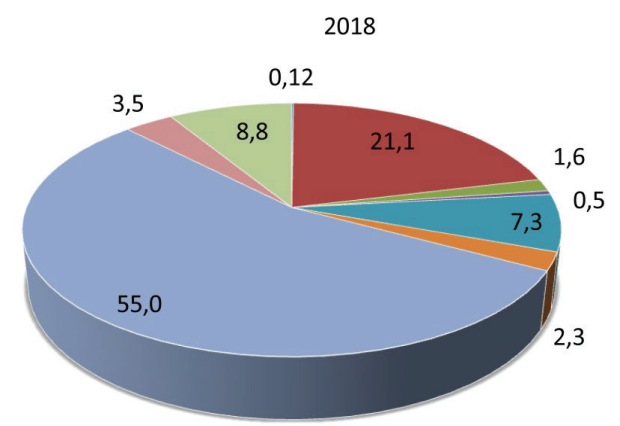

$d$

Fig. 1. Equity participation of the studied factors in the formation of soy bean yields, by 2015-2018 \%: $a$-studied factors for 2015; $b$ - studied factors for 2016; $c$-studied factors for 2017 ; $d$ - studied factors for 2018

Coding in the figures:

- factor $a$ - grade;

- factor $c$ - inoculation;

- factor $b$ - micronutrient fertilizers;

- factor $c b c$ - two different inoculants, combined with micronutrient fertilization;

- factor $c a c$ - two different inoculants and variety;

- factor $c a b$ - inoculant, variety, micronutrient fertilizer;

- factor $c a b c$ - two different inoculants, variety, micronutrient fertilizer;

- factor $c p$ - scattering (influence) of repetitions;

- factor $c z$ - error dispersion.

Analysis of variance showed that in terms of factors, factor $a$ (variety) turned out to be more influential in 2015 - by $52.2 \%$.The second largest was the indicator of $c b c$ factors (two different inoculants in combination with micronutrient fertilizers) and amounted to $18.5 \%$, factor $c$ (inoculation) influenced $1.4 \%$, the share of factor $c b c$ (micronutrient fertilization) was $1.7 \%$.

Accordingly, in 2016, the analysis of variance showed that in the context of factors, the more influential factor - by $51.7 \%$, was the indicator of CBC factors (two different inoculants in combi- 
nation with micronutrient fertilizers). Factor $a$ (variety) was 17.3 factor $c$ (inoculation) influenced by $0.4 \%$, the share of the factor $b$ influence (micronutrient fertilizers) was $6.2 \%$.

The analysis of variance showed that in terms of factors, factor $a$ (variety) turned out to be more influential in 2017 - by $35.2 \%$, the second largest was the indicator of $c b c$ factors (two different inoculants in combination with micronutrient fertilizers) and amounted to $16.6 \%$. Factor $c b c$ (inoculation) influenced $2.5 \%$, the share of factor $b$ (micronutrient fertilization) was $5.5 \%$.

Accordingly, in 2018, the analysis of variance showed that in the context of factors, the more influential factor - by $55.5 \%$ was the indicator of $c b c$ factors (two different inoculants in combination with micronutrient fertilizers). Factor of (variety) was 21.1 factor $c$ (inoculation) by $0.5 \%$, the share of influence of factor $b$ (micronutrient fertilizers) was $1.6 \%$.

In the variants with repeated introduction of micronutrient fertilizers, the variety Maxus and Cordoba reacted in the best conditions under the conditions of the current drought and the increase is $0.23-0.72 \mathrm{t} / \mathrm{ha}$ before a single use of microfertilizer is $0.02-0.07 \mathrm{t} / \mathrm{ha}$. In the variant with Saska varieties, where the application of micronutrient fertilizers with sulfur content, the yield increase was $0.01-0.03 \mathrm{t} /$ ha, respectively, this is $0.11-0.20-0.26 \%$. Thus, the 2016 weather conditions made significant adjustments to the yield of soybean varieties. All varieties of experience responded positively to a much lesser extent to the use of inoculants, especially good indicators of the experiment variant with the inoculant HaiKot and mixtures HaiKot and High Kot + Chi Stik, the use of micronutrients gave an economically feasible increase in productivity. Weather and climatic conditions in 2016 did not allow all varieties to fully reveal their genetic potential

The weather and climatic conditions of 2017 compared with the last vegetation year (2016) were more favorable for growing crops. The moisture lack both in soil and in the air made adjustments to the yield of soybean varieties depending on the ripeness group. According to Table 1, yield indicators demonstrate that the early ripening variety Maxus and mid-ripening variety Cordoba, according to technological methods, carried out in accordance with the research scheme, provide yield growth. This is due to the fact that the early ripening variety Maxus and mid-ripening variety Cordoba were in conditions of insufficient moisture and its further decrease, starting from the second decade of July until the end of the third decade of August. Harvest formation by Maxors and Cordoba crops (laying of beans, filling) occurred with a moderate presence of moisture both in soil and in air. In the late-ripening varieties of Saska, flowering processes, laying of beans, poured them for the first and fourth tiers occurred under relatively favorable conditions. From the second decade of July until the third decade of August, the temperature rose to $30-40{ }^{\circ} \mathrm{C}$, and the relative humidity dropped to $25-40 \%$, as a result of which the flowers and planted beans were aborted. This is due to the fact that the second application to the Bospholiaru, which took place at the beginning of the first decade of July, negatively affected the crop, as shown by the yield results in the table below.

In extreme weather and climatic conditions of 2017, the micronutrient fertilizers usage with low moisture reserves in soil, air and, accordingly, low sap flow in a plant of late-ripening soybean varieties negatively affected crop yields. On varieties of Saska variety, bean cracking was often seen for an hour, while on the variant with a single use of Vuksal Boron this did not happen. Therefore, this should be taken into account in the future, when growing soybean varieties of any ripeness group and long-term weather forecast. Processing soybean crops should be carried out in the presence of optimal productive moisture of the soil, plants should not be under stress.

After analyzing the data of Table 1, it can be seen, that in the variant without inoculants, but using VuksalBoron microfertilizer, regardless of the ripeness group of soybean varieties, a yield increase of $0.05 \mathrm{t} /$ ha to $0.22 \mathrm{t} / \mathrm{ha}$ is obtained, which is $2.0-12.5 \%$, respectively. The reuse of Bospholiar made it possible to obtain an additional $0.11 \mathrm{t} /$ ha to $0.21 \mathrm{t} / \mathrm{ha}$, but the maximum result was on Maxus variety $-2.1 \mathrm{t} / \mathrm{ha}$, while Saska variety provided an additional $0.11 \mathrm{t} / \mathrm{ha}$.

The weather and climatic conditions of 2018 in comparison with the last vegetation year (2017) are more favorable for growing crops.

In 2018, the use of inoculants and Vuksal Boron on soy was fully justified. So in the budding phase, the beginning of flowering use of Vuksal Boron gave the following positive results. So, the early ripening variety Maxus added $0.81 \mathrm{t} /$ ha to the control over the use of the Hi Stik drug, and let the Hai Kot Super+HaiKot Super Extender 0.91 t/ha with the use of the inoculant. The mid-season 
Cordoba variety is $0.65 \mathrm{t} / \mathrm{ha}$ and $0.77 \mathrm{t} / \mathrm{ha}$. Remarkable results were also obtained for late-ripening varieties, so using the Chi Stoke preparation was obtained in accordance with the control of $0.97 \mathrm{t} / \mathrm{ha}$, and using the inoculant, HaiKot Super+HaiKot Super Extender $0.85 \mathrm{t} / \mathrm{ha}$.

Processing soybean seeds with a complex of inoculants Hai Kot Super+Hai Kot Super Extender and Hi Stik and use them for vegetation during budding.The beginning of flowering Vuksal Boron received the following crop increases, the early ripening variety Maxus added $1.27 \mathrm{t} / \mathrm{ha}$ to the control. The mid-ripening Cordoba variety, respectively $1.05 \mathrm{t} / \mathrm{ha}$, and the late-ripening variety Saska 1.09 t/ha.

The weather and climatic conditions of 2018 again made adjustments to the size of the crop of soybean varieties, regardless of the ripeness and reuse groups of Bospoliaru, all varieties reacted positively in yield increase. Reuse of microfertilizers in the bean loading phase reduced the yield increase from $33.6 \%$ to $21.4 \%$ with a single use of Vuksal Boron and up to $27.8 \%$ with a maximum of $10.4 \%$ with repeated use of Bospholiaru.

The weather and climatic conditions of 2018 allowed early and mid-ripening soybean varieties to reveal their genetic potential. The late-ripening Saska variety once again during the period of the experiments lacks productive soil moisture and air humidity, which negatively affects the flowering and setting of beans and their subsequent abortion. Ultimately, this is a shortage of crops and not stable economic efficiency of growing crops.

After conducting research on different ripeness groups from soybean varieties, such as Maxus, Cordoba, Sasuke, they received positive results from the use of inoculants.

Consequently, an increase in soybean production is possible only through the improvement of existing and the development of new elements of the technology for its cultivation, using new nutritional products.The use of inoculants, containing modern, highly effective, culture-specific strains of rhizobial bacteria with increased viability in high concentrations, ensures the formation of the maximum number of vesicles on the root system of plants.The combination of the inoculation process and the use of micronutrient fertilizers in the growing technology, as the results of the study show, give significant results in increasing yields.

\section{Conclusions}

An integral part of technological measures that make it possible to realize the potential of the soybean genotype is balanced mineral nutrition, not only the main elements (nitrogen, phosphorus, potassium), but also trace elements. One of the most effective measures to improve the growth and development of soybean plants, and, accordingly, its productivity, is the use of micronutrients.

The use of inoculants, containing modern, highly effective, culture-specific strains of rhizobial bacteria with increased viability in high concentrations, ensure the formation of the maximum number of bubbles on the root system of soy plants.

The combination of the inoculation process and the use of micronutrient fertilizers in growing technology give significant results and increased yields. The relative air humidity and productive soil moisture reserves should be considered.

Based on the results of the preliminary study, it is planned to develop a basic version of the technology for growing soybeans using inoculants and micronutrient fertilizers in the southwestern part of the Forest-Steppe of Ukraine.

\section{References}

[1] Petrychenko, V. F., Lykhochvor, V. V. (2014). Roslynnytstvo. Tekhnolohiyi vyroshchuvannia silskohospodarskykh kultur. Lviv: NFF «Ukrainski tekhnolohiyi», 492.

[2] Shevnikov, M. Ya., Koblai, O. O. (2015). Zastosuvannia biolohichnykh, khimichnykh ta fizychnykh zasobiv u tekhnolohiyakh vyroshchuvannia soi ta kukurudzy. Poltava: FOP Kriukov Yu.F., 228.

[3] Babych, A. O. (2000). Produktyvnyi potentsial sortiv soi dlia rehioniv Ukrainy. Propozytsiya, 11, 38-39.

[4] Lihochvor, V. (2008). Osobennosti listovoy podkormki. Zerno, 5, 48-53.

[5] Marchuk, I. (2009). Suchasni dobryva - na varti vrozhaiu. Propozytsiya, 4, 42-45.

[6] Moskalets, V. V., Shynkarenko, V. K. (2004). Zastosuvannia mikrobnykh preparativ i mikroelementnykh dobryv na yakist zerna soi. Ahroekolohichnyi zhurnal, 3, 19-24. 
[7] Bakhmat, M. I., Bakhmat, O. M. (2001). Rozrobka tekhnolohichnykh zakhodiv dlia otrymannia ekolohichnoho zerna soi v umovakh Zakhidnoho Lisostepu. Kormy i kormovyrobnytstvo, 47, 105-106.

[8] Bakhmat, O. M., Fedoruk, I. V. (2017). Formation of Soybean Grain Yield Depending on Measures Adaptive Technology Under Westen Forest Steppe. Podilian Bulletin: agriculture, engineering, economics, 26 (1), 9-16.

[9] Singha, G. (Ed.) (2014). Soya: biologiya, proizvodstvo, ispol'zovanie. Ludhiana: Zerno, 650.

[10] Petrychenko, V. F., Lykhochvor, V. V., Ivaniuk, S. V. et. al. (2016). Soia. Vinnytsia: Dilo, 392.

[11] Babych, A. O., Babych-Poberezhna, A. A. (2011). Selektsiya, vyrobnytstvo, torhivlia i vykorystannia soi v sviti. Kyiv, 548.

[12] Fedoryk, I. V. (2019). Impact of seed inoculation on soy crop. Taurian Scientific Herald, 108, 110-116. doi: https://oi.org/ 10.32851/2226-0099.2019.108.15

[13] Melnyk, S. I., Zhylkin, V. A., Havryliuk, M. M. et. al. (2007). Rekomendatsiyi z efektyvnoho zastosuvannia mikrobnykh preparativ u tekhnolohiyakh vyroshchuvannia silskohospodarskykh kultur. Kyiv, 55.

[14] Vid khoroshoho do krashchoho. Inokulianty kompaniyi BASF (2015). Ahrobiznes sohodni. Available at: http://agro-business. com.ua/2017-09-29-05-56-43/item/2231-vid-khoroshoho-do-krashchoho-inokulianty-kompanii-basf.html

[15] Babich, A. A. (1974). Sortovaya reaktsiya soi na sroki poseva, izmenenie gustoty rasteniy i usloviya pitaniya. Doklady VASHNIL, 10, 14-17.

Received date 08.02.2021

Accepted date 19.03.2021

Published date 31.03.2021
(C) The Author(s) 2021

This is an open access article under the CC BY license (http://creativecommons.org/licenses/by/4.0).

How to cite: Fedoruk, I., Bakhmat, O., Khmelianchyshyn, Y., Gorodyska, O. (2021). Agroecological influence of micronutrient fetilizers and seed inoculation on a soybean crop. EUREKA: Life Sciences, 2, 16-24. doi: https://doi.org/10.21303/2504-5695.2021.001747 